\title{
PROPERTIES AND STRUCTURE OF Cu-Ti-Zr-Ni AMORPHOUS POWDERS PREPARED BY MECHANICAL ALLOYING
}

\author{
LASTNOSTI IN STRUKTURA AMORFNIH PRAHOV Cu-Ti-Zr-Ni, \\ PRIPRAVLJENIH Z MEHANSKIM LEGIRANJEM
}

\author{
Aleksandra Guwer, Ryszard Nowosielski, Anna Lebuda \\ Silesian University of Technology, Faculty of Mechanical Engineering, Institute of Engineering Materials and Biomaterials, Konarskiego Street \\ 18A, 44-100 Gliwice, Poland \\ aleksandra.guwer@polsl.pl
}

Prejem rokopisa - received: 2014-07-26; sprejem za objavo - accepted for publication: 2014-09-02

doi:10.17222/mit.2014.119

\begin{abstract}
The method of fabrication, an investigation and a comparison of the structure, size and shape of grains of a quaternary $\mathrm{Cu}-\mathrm{Ti}-\mathrm{Zr}-\mathrm{Ni}$ alloy were investigated. Cu-based amorphous alloys have a high strength, ductility, fracture toughness, fatigue strength and excellent corrosion resistance in solutions such as $\mathrm{H}_{2} \mathrm{SO}_{4}, \mathrm{NaOH}, \mathrm{NaCl}$ and $\mathrm{HNO}_{3}$. Samples of powders were prepared by mechanical alloying in a high-energy ball mill SPEX 8000. To obtain the amorphous structure of the $\mathrm{Cu}_{47} \mathrm{Ti}_{34} \mathrm{Zr}_{11} \mathrm{Ni}_{8}$ powder, various milling times were used. Finally, four samples for testing were obtained with pure $\mathrm{Cu}, \mathrm{Ti}, \mathrm{Ni}, \mathrm{Zr}(99.99 \%)$. The structure of the $\mathrm{Cu}_{47} \mathrm{Ti}_{34} \mathrm{Zr}_{11} \mathrm{Ni}_{8}$ powders was examined by X-ray diffraction (XRD) after $7 \mathrm{~h}, 8 \mathrm{~h}, 9 \mathrm{~h}$ and $10 \mathrm{~h}$ of milling time. The chemical composition, particle size and shape of the prepared powders were investigated by scanning electron microscopy (SEM). The microhardness was measured by using a Vickers hardness-testing machine with automatic track measurement. The fully amorphous powders were obtained after $10 \mathrm{~h}$ of milling. The prolonged time of milling resulted in an increased particle size and a changed shape of the powders. The highest microhardness was obtained for the amorphous samples.

In further work the studied amorphous powders will be consolidated using spark-plasma sintering, which is an innovative method for the production of amorphous alloys.
\end{abstract}

Keywords: mechanical alloying, Cu-based amorphous alloys, SEM, XRD, microhardness

Preiskovan je bil način izdelave, preiskava in primerjava strukture, velikosti in oblike zrn kvaternerne zlitine $\mathrm{Cu}-\mathrm{Ti}-\mathrm{Zr}-\mathrm{Ni}$. Amorfne zlitine na osnovi $\mathrm{Cu}$ imajo visoko trdnost, duktilnost, lomno žilavost, odpornost proti utrujanju in odlično odpornost proti koroziji v raztopinah $\mathrm{H}_{2} \mathrm{SO}_{4}, \mathrm{NaOH}, \mathrm{NaCl}$ in $\mathrm{HNO}_{3}$. Vzorci prahov so bili pripravljeni z mehanskim legiranjem $\mathrm{v}$ visokoenergijskem krogličnem mlinu SPEX 8000. Za zagotovitev amorfne strukture prahu $\mathrm{Cu}_{47} \mathrm{Ti}_{34} \mathrm{Zr}_{11} \mathrm{Ni}_{8}$ so bili uporabljeni različni časi mletja. Iz čistega $\mathrm{Cu}, \mathrm{Ti}, \mathrm{Ni}, \mathrm{Zr}(99,99 \%)$ so bili izdelani štirje preizkušanci. Struktura prahov $\mathrm{Cu}_{47} \mathrm{Ti}_{34} \mathrm{Zr}_{11} \mathrm{Ni}_{8}$ je bila pregledana z rentgensko difrakcijo (XRD) po $7 \mathrm{~h}, 8 \mathrm{~h}, 9 \mathrm{~h}$ in $10 \mathrm{~h}$ mletja. Kemijska sestava, velikost in oblika delcev pripravljenih prahov je bila preiskana $\mathrm{z}$ vrstičnim elektronskim mikroskopom (SEM). Mikrotrdota je bila izmerjena $\mathrm{z}$ avtomatsko napravo za merjenje trdote po Vickersu. Popolnoma amorfni prahovi so bili dobljeni po $10 \mathrm{~h}$ mletja. Pri podaljšanju časa mletja je narasla velikost in spremenila se je oblika delcev prahov. Najvišjo mikrotrdoto so imeli amorfni vzorci.

$\mathrm{V}$ nadaljevanju dela bodo preiskovani amorfni prahovi, sintrani z uporabo iskrilnega plazemskega sintranja, ki je inovativna metoda za izdelavo amorfnih zlitin.

Ključne besede: mehansko legiranje, amorfne zlitine na osnovi $\mathrm{Cu}$, SEM, XRD, mikrotrdota

\section{INTRODUCTION}

Bulk amorphous metallic alloys exhibit many superior properties compared to crystalline alloys. Lately, it has been noted that rods and ribbons of $\mathrm{Cu}$-based alloys demonstrate a high tensile strength, fatigue strength, fracture strength, ductility, relatively low cost of products, a good glass-forming ability and excellent corrosion resistance in solutions such as $\mathrm{H}_{2} \mathrm{SO}_{4}, \mathrm{NaOH}, \mathrm{NaCl}$ and $\mathrm{HNO}_{3}{ }^{1-5}$.

The most frequently encountered methods for the preparation of amorphous materials are casting methods. An alternative process to prepare amorphous alloys is mechanical alloying combined with the method of spark-plasma sintering. Using this production method $\mathrm{Cu}$-based amorphous alloys were produced by, e.g., Kim et al. ${ }^{6}$ and $\mathrm{Chu}$ et al. ${ }^{7}$

Mechanical alloying (MA) is defined as a highenergy milling process during which the particles are subjected to multiple cold welding, cracking and re-welding. With rapid cold deformation the specimen's temperature is increased because of the transformation of the mechanical work into heat. The MA process allows the alloying of elements that are difficult or impossible to combine by conventional casting methods. The products of MA are advanced materials, including equilibrium, non-equilibrium (amorphous, quasicrystals, nanocrystalline) and composite materials. The final material properties depend on the MA process parameters (kind of mill, size and amount of grinding media, temperature and atmosphere of milling, ratio of grinding media mass to powder mass, etc. $)^{8,9}$.

In this paper we report on the fabrication and an investigation of $\mathrm{Cu}_{47} \mathrm{Ti}_{34} \mathrm{Zr}_{11} \mathrm{Ni}_{8}$ alloy powder prepared by mechanical alloying. The purpose of the present work was to obtain amorphous powders that could be sintered in the future. 


\section{EXPERIMENTAL}

\subsection{Materials}

Four samples with the composition $\mathrm{Cu}_{47} \mathrm{Ti}_{34} \mathrm{Zr}_{11} \mathrm{Ni}_{8}$ were prepared using elemental powders of copper, titanium, zirconium and nickel $(99.99 \%$ purity, < 325 mesh). Each sample was prepared with $8 \mathrm{~g}$ of properly weighed powders. The masses and melting points ${ }^{10}$ of the individual elements $(\mathrm{Cu}, \mathrm{Ti}, \mathrm{Zr}, \mathrm{Ni})$ are shown in Table 1. The powder composition was weighed on an analytical high-precision balance AS/X.

Table 1: Characteristics of used elements $(\mathrm{Cu}, \mathrm{Ti}, \mathrm{Zr}, \mathrm{Ni})$

Tabela 1: Značilnosti uporabljenih elementov $(\mathrm{Cu}, \mathrm{Ti}, \mathrm{Zr}, \mathrm{Ni})$

\begin{tabular}{|c|c|c|c|}
\hline Powder & $x / \%$ & $m(8 \mathrm{~g}) / \mathrm{g}$ & $T_{\mathrm{m}} /{ }^{\circ} \mathrm{C}$ \\
\hline Copper & 47 & 3.9252 & $1085^{10}$ \\
\hline Titanium & 34 & 2.1389 & $1670^{10}$ \\
\hline Zirconium & 11 & 1.3187 & $1854^{10}$ \\
\hline Nickel & 8 & 0.6170 & $1453^{10}$ \\
\hline
\end{tabular}

$x / \%$ - amount fraction

$x / \%$ - množinski delež

\subsection{Research methodology}

Four different milling times were applied: (7, 8, 9, 10) $\mathrm{h}$. The process of mechanical alloying was interrupted every $30 \mathrm{~min}$ for $30 \mathrm{~min}$ to lower the temperature of the crucible and the powders. Cr steel balls of $13 \mathrm{~mm}$ diameter were used and the ball-to-powder weight ratio was $5: 1$. The powder mixture and the $\mathrm{Cr}$ steel balls were placed in an austenitic crucible in an argon atmosphere inside a glove bag, as shown in Figure 1.

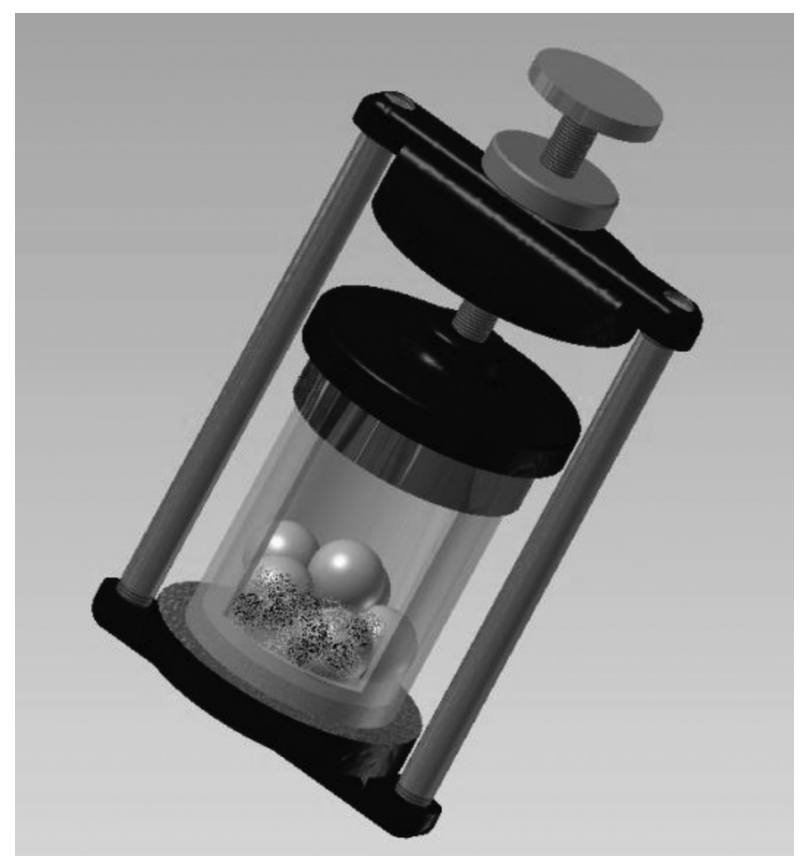

Figure 1: Schematic illustration of the cylindrical steel vessel placed in the holder inside the SPEX 8000 mill

Slika 1: Shematski prikaz cilindrične jeklene posode, postavljene v mlin SPEX 8000
A high-energy ball mill SPEX 8000 CertiPrep Mixer/ Mill "shaker" type was used, which generated vibrations of the balls and the powder inside the container ${ }^{11,12}$.

An X-ray diffractometer X'Pert Pro Panalytical and radiation $(\lambda \mathrm{Co}-K \alpha)$ of $0.178897 \mathrm{~nm}$ were used to study the structure of the obtained powders. The data of the diffraction lines were recorded using the "step-scanning" method in the $2 \theta$ range from $30^{\circ}$ to $70^{\circ}$ and with a $0.013^{\circ}$ step. The time of the step was $40 \mathrm{~s}$ and the scanning speed was $0.084^{\circ} \mathrm{s}^{-1}$.

The particles size and shape of the $\mathrm{Cu}_{47} \mathrm{Ti}_{34} \mathrm{Zr}_{11} \mathrm{Ni}_{8}$ powders were assessed using the microscope SEM SUPRA 25 ZEISS with a magnification up to 500-times

The chemical compositions of the samples were measured with energy-dispersive X-ray spectroscopy (EDS) with an EDS analyzer as part of the SEM. The values of the characteristic radiation energy allow a qualitative analysis in the test sample, and the intensity (peaks height) allows for a quantitative analysis.

The microhardnesses of the particles were measured by the Vickers tester with automatic track measurement using image analysis FUTURETECH FM-ARS 9000. The microhardness measurements were made under a load of $0.97 \mathrm{~N}$. In each of the prepared samples, seven particles were tested.

\section{RESULTS AND DISCUSSION}

\subsection{XRD analysis}

Figure 2 demonstrates the XRD patterns of the $\mathrm{Cu}_{47} \mathrm{Ti}_{34} \mathrm{Zr}_{11} \mathrm{Ni}_{8}$ powders after different milling times (7 h, $8 \mathrm{~h}, 9 \mathrm{~h}, 10 \mathrm{~h}$ ). After $7 \mathrm{~h}$ of mechanical alloying there is no significant change in the position of the diffraction peaks and the slightly diminished intensity of those peaks is observed. After $8 \mathrm{~h}$ and $9 \mathrm{~h}$ of processing the broadening and intensity reduction of the crystalline diffraction lines were observed and a maximum broad diffuse diffraction started to form, and after $10 \mathrm{~h}$ of milling the samples were amorphous. The diffraction pattern shows a single broad diffraction halo with the $2 \theta$ range of $43-54^{\circ}$ from the amorphous phase without simple peaks (Figure 2d).

The same alloy was tested by Shengzhong et al. ${ }^{13}$ The team of researchers used different process parameters for a QM-1SP planetary high-energy ball miller and pure elemental powders, i.e., $99.9 \%$. The process of mechanical alloying was interrupted every hour for 30 min. They obtained an amorphous phase after $8 \mathrm{~h}, 9 \mathrm{~h}$, $10 \mathrm{~h}$ and $12.5 \mathrm{~h}$ of milling time.

The amorphous structure of the $\mathrm{Cu}_{50} \mathrm{Ti}_{50}$ powders was obtained after $8 \mathrm{~h}$ of mechanical alloying by using identical parameters to those indicated in this article ${ }^{14}$.

\subsection{Microstructure}

Figure 3 shows the powders after: a) 7 h, b) 8 h, c) 9 $\mathrm{h}, \mathrm{d}) 10 \mathrm{~h}$ of milling time. The initial size of the powders 
A. GUWER et al.: PROPERTIES AND STRUCTURE OF Cu-Ti-Zr-Ni AMORPHOUS POWDERS ..

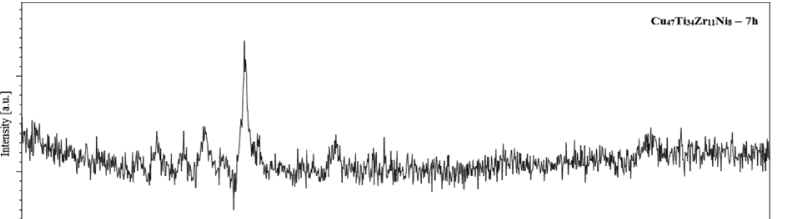

(a)
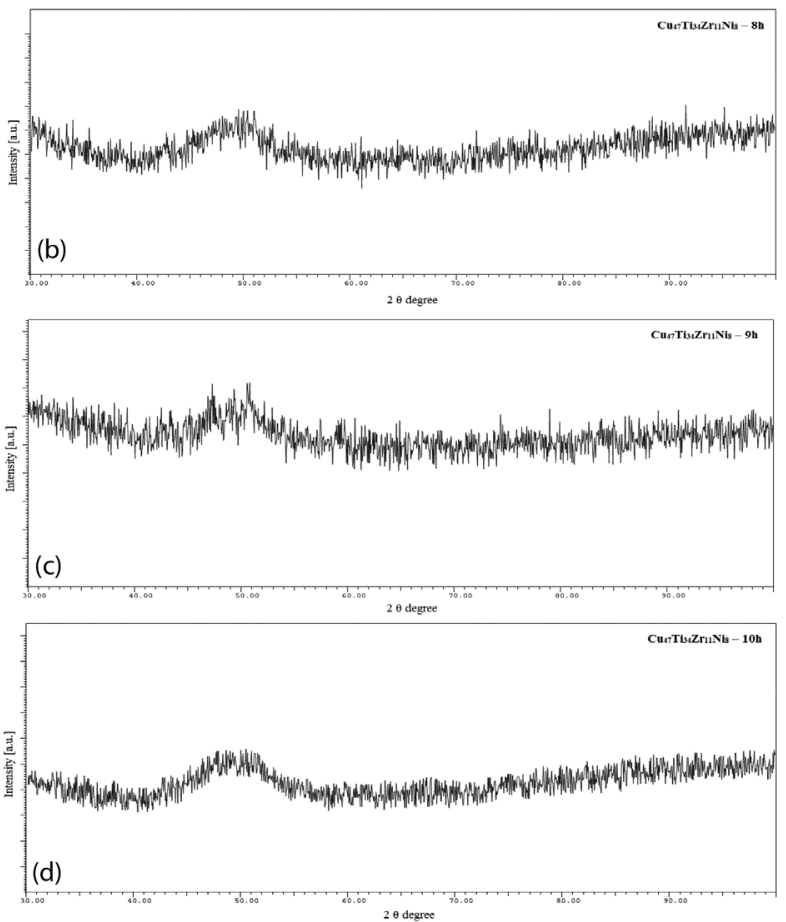

Figure 2: $\mathrm{X}$-ray diffraction pattern of $\mathrm{Cu}_{47} \mathrm{Ti}_{34} \mathrm{Zr}_{11} \mathrm{Ni}_{8}$ powders after: a) $7 \mathrm{~h}$, b) $8 \mathrm{~h}$, c) $9 \mathrm{~h}, \mathrm{~d}) 10 \mathrm{~h}$ of mechanical alloying

Slika 2: Posnetek rentgenske difrakcije prahov $\mathrm{Cu}_{47} \mathrm{Ti}_{34} \mathrm{Zr}_{11} \mathrm{Ni}_{8}$ po: a) $7 \mathrm{~h}, \mathrm{~b}) 8 \mathrm{~h}$, c) $9 \mathrm{~h}$, d) $10 \mathrm{~h}$ mehanskega legiranja
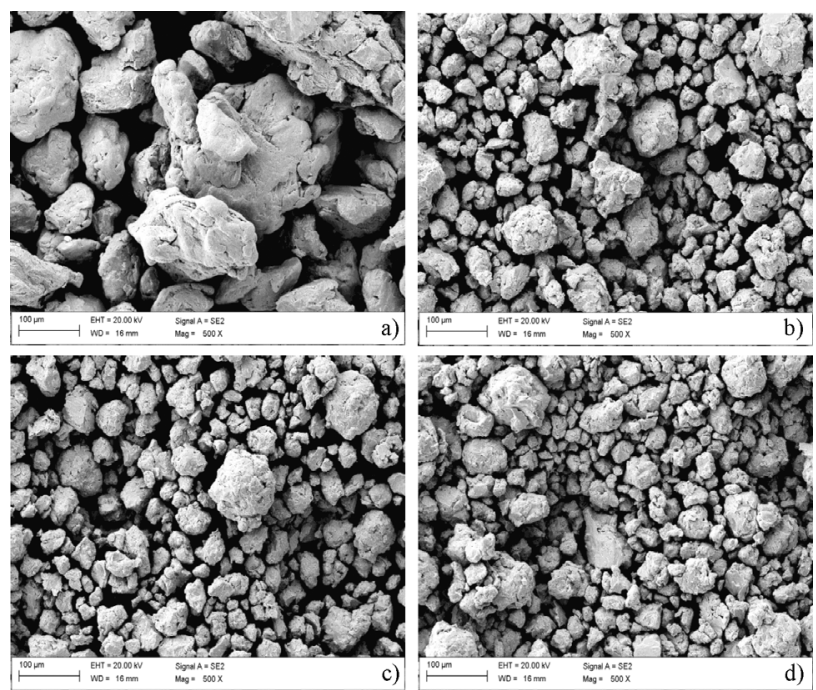

)

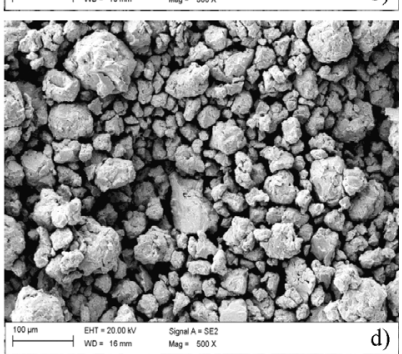

Figure 3: Shape and size of $\mathrm{Cu}_{47} \mathrm{Ti}_{34} \mathrm{Zr}_{11} \mathrm{Ni}_{8}$ powder after: a) $7 \mathrm{~h}$, b) 8 $\mathrm{h}$, c) $9 \mathrm{~h}$, d) $10 \mathrm{~h}$ of mechanical alloying, (SEM, magnifications 500-times)

Slika 3: Oblika in velikost prahu $\mathrm{Cu}_{47} \mathrm{Ti}_{34} \mathrm{Zr}_{11} \mathrm{Ni}_{8}$ po: a) $7 \mathrm{~h}$, b) $8 \mathrm{~h}$, c) $9 \mathrm{~h}, \mathrm{~d}) 10 \mathrm{~h}$ mehanskega legiranja, (SEM, povečava 500-kratna) was about $44 \mu \mathrm{m}$. As a result of the mechanical synthesis the powders changed their size and shape. The largest particles were found after $7 \mathrm{~h}$ of milling time $(238 \mu \mathrm{m} \times$ $143 \mu \mathrm{m})$. During this milling time, the particles were stuck to large agglomerates, then after $8 \mathrm{~h}$ of milling time the particles disintegrated, because after $8 \mathrm{~h}$ of milling the particles were crushed to a smaller average of 47 $\mu \mathrm{m} \times 25 \mu \mathrm{m}$. By using longer milling times $(9 \mathrm{~h}, 10 \mathrm{~h})$, the particles size was increased and their shape became more homogeneous and spherical. However, their size was below that after $7 \mathrm{~h}$ of milling time. The average size of the particles after the milling time is listed in Table 2.

Table 2: Average particle size $(\mu \mathrm{m})$ of the MA powders Tabela 2: Povprečna velikost delcev $(\mu \mathrm{m}) \mathrm{MA}-$ prahov

\begin{tabular}{|c|c|c|c|c|}
\hline $\begin{array}{c}\text { Time of mechani- } \\
\text { cal alloying }(\mathrm{h})\end{array}$ & 7 & 8 & 9 & 10 \\
\hline $\begin{array}{c}\text { Average particle } \\
\text { size }(\mu \mathrm{m})\end{array}$ & $238 \times 143$ & $47 \times 25$ & $63 \times 41$ & $87 \times 62$ \\
\hline
\end{tabular}
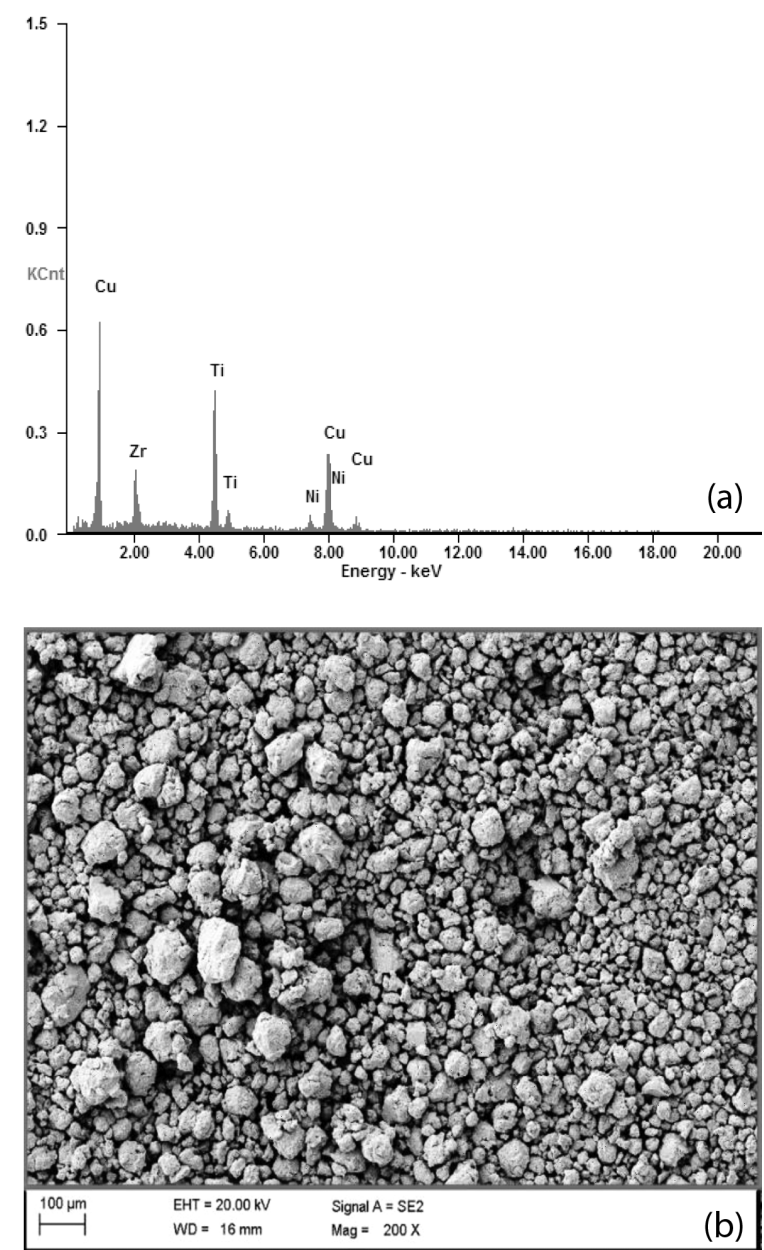

Figure 4: a) EDS spectrum with marked EDS X-ray lines and b) SEM micrographs of $\mathrm{Cu}_{47} \mathrm{Ti}_{34} \mathrm{Zr}_{11} \mathrm{Ni}_{8}$ powders after $10 \mathrm{~h}$ of mechanical alloying with 30 min interruption

Slika 4: a) EDS-spekter z označenimi EDS rentgenskimi linijami in b) SEM-posnetek prahov $\mathrm{Cu}_{47} \mathrm{Ti}_{34} \mathrm{Zr}_{11} \mathrm{Ni}_{8}$ po $10 \mathrm{~h}$ mehanskega legiranja s prekinitvijo $30 \mathrm{~min}$ 
Figure 4 depicts the XRD spectrum and the analyzed area of the $\mathrm{Cu}_{47} \mathrm{Ti}_{34} \mathrm{Zr}_{11} \mathrm{Ni}_{8}$ powder after $10 \mathrm{~h}$ of milling. Energy-dispersive X-ray analysis (EDS) shows the X-ray lines of copper, titanium, zirconium and nickel elements in the sample. The amount of $\mathrm{Cu}, \mathrm{Zr}, \mathrm{Ni}$ and $\mathrm{Ti}$ depends on the time of milling. Table 3 presents the detailed results of the chemical analysis for every sample. The particles contain the basic components ( $\mathrm{Ti}, \mathrm{Cu}, \mathrm{Zr}$ and $\mathrm{Ni}$ ). The initial atomic percentage of $\mathrm{Cu}$ equals $47 \%$, for $\mathrm{Ti}$ it is $34 \%$, for $\mathrm{Zr}$ it is $11 \%$ and for $\mathrm{Ni}$ it is $8 \%$. The results indicate that the obtained powder particles after the alloying process have a very similar atomic composition compared to the initial weighed composition. The chemical composition of the milled powders confirms the existence of the metals identified from the XRD spectra.

Table 3: Chemical composition of the powders surface Tabela 3: Kemijska analiza površine prahov

\begin{tabular}{|c|c|c|}
\hline Milling Time (h) & Element & $x / \%$ \\
\hline \multirow{4}{*}{0} & $\mathrm{Cu}$ & 47 \\
\hline & $\mathrm{Ti}$ & 34 \\
\hline & $\mathrm{Zr}$ & 11 \\
\hline & $\mathrm{Ni}$ & 8 \\
\hline \multirow{4}{*}{7} & $\mathrm{Cu}$ & 50.61 \\
\hline & $\mathrm{Ti}$ & 32.89 \\
\hline & $\mathrm{Zr}$ & 09.23 \\
\hline & $\mathrm{Ni}$ & 07.27 \\
\hline \multirow{4}{*}{8} & $\mathrm{Cu}$ & 49.58 \\
\hline & $\mathrm{Ti}$ & 33.02 \\
\hline & $\mathrm{Zr}$ & 9.82 \\
\hline & $\mathrm{Ni}$ & 7.58 \\
\hline \multirow{4}{*}{9} & $\mathrm{Cu}$ & 48.73 \\
\hline & $\mathrm{Ti}$ & 33.43 \\
\hline & $\mathrm{Zr}$ & 10.02 \\
\hline & $\mathrm{Ni}$ & 7.82 \\
\hline \multirow{4}{*}{10} & $\mathrm{Cu}$ & 51.50 \\
\hline & $\mathrm{Ti}$ & 30.94 \\
\hline & $\mathrm{Zr}$ & 08.98 \\
\hline & $\mathrm{Ni}$ & 08.57 \\
\hline
\end{tabular}

\subsection{Microhardness}

The microhardness was measured on pressed powders with ten indentations for each sample and are shown in Figure 5. The deduced average microhardness after milling times $(7 \mathrm{~h}, 8 \mathrm{~h}, 9 \mathrm{~h}, 10 \mathrm{~h})$ is shown in Table 4. The highest average microhardness was obtained for the powders after $10 \mathrm{~h}$ of milling time $(553 \mathrm{HV})$, i.e., for the powders with the fully amorphous structure. The average microhardness increases with the milling time. The difference between the lowest $334 \mathrm{HV}$, after $7 \mathrm{~h}$ of

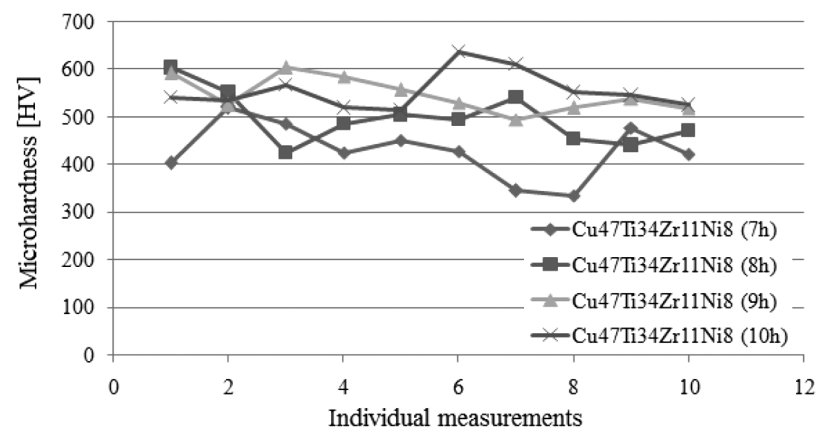

Figure 5: Powders microhardness after different milling times Slika 5: Mikrotrdote prahov po različnih časih mletja

milling, and the highest (518 HV), after $10 \mathrm{~h}$ of milling, was $184 \mathrm{HV}$. This indicates the great heterogeneity of the obtained particles. The average microhardness of the amorphous powder $\mathrm{Cu}_{47} \mathrm{Ti}_{34} \mathrm{Zr}_{11} \mathrm{Ni}_{8}(553 \mathrm{HV})$ is higher than that of the amorphous powders $\mathrm{Cu}_{50} \mathrm{Ti}_{50}(542 \mathrm{HV}){ }^{14}$

\section{CONCLUSIONS}

The result of the tests and the examination of the $\mathrm{Cu}_{47} \mathrm{Ti}_{34} \mathrm{Zr}_{11} \mathrm{Ni}_{8}$ powders lead to the following conclusions:

- It is possible to obtain an amorphous structure for a four-component alloy $\mathrm{Cu}_{47} \mathrm{Ti}_{34} \mathrm{Zr}_{11} \mathrm{Ni}_{8}$ by using mechanical synthesis in a SPEX 8000 mill.

- An amorphous structure was obtained for the $10 \mathrm{~h}$ milling-time sample.

- The largest particles are obtained after $7 \mathrm{~h}$ milling and the smallest after $8 \mathrm{~h}$ milling. The largest shape and the best size regularity were obtained for the amorphous powders.

- The presence of the initial elements $\mathrm{Cu}, \mathrm{Ti}, \mathrm{Zr}, \mathrm{Ni}$ in the milled particles was confirmed. The content of elements in the milled powders corresponds to the initial weighed composition.

- The average microhardness value increases with the milling time and the highest hardness is achieved in the amorphous sample (553 HV).

\section{Acknowledgments}

The work was partially supported by the National Science Centre under research Project No.: 2012/07/N/ ST8/03437.

Table 4: Average microhardness after different mechanical-alloying times

Tabela 4: Spreminjanje povprečne mikrotrdote pri različnem trajanju mehanskega legiranja

\begin{tabular}{|c|c|c|c|c|}
\hline Samples & $\mathrm{Cu}_{47} \mathrm{Ti}_{34} \mathrm{Zr}_{11} \mathrm{Ni}_{8}(7 \mathrm{~h})$ & $\mathrm{Cu}_{47} \mathrm{Ti}_{34} \mathrm{Zr}_{11} \mathrm{Ni}_{8}(8 \mathrm{~h})$ & $\mathrm{Cu}_{47} \mathrm{Ti}_{34} \mathrm{Zr}_{11} \mathrm{Ni}_{8}(9 \mathrm{~h})$ & $\mathrm{Cu}_{47} \mathrm{Ti}_{34} \mathrm{Zr}_{11} \mathrm{Ni}_{8}(10 \mathrm{~h})$ \\
\hline The average microhardness (HV) & 428 & 496 & 545 & 553 \\
\hline
\end{tabular}




\section{REFERENCES}

${ }^{1}$ P. Lee, C. Yao, J. Chen, L. Wang. R. Jeng, Y. Lin, Preparation and thermal stability of mechanically alloyed $\mathrm{Cu}-\mathrm{Zr}-\mathrm{Ti}-\mathrm{Y}$ amorphous powders, Materials Science and Engineering A, 375-377 (2004), 829-833, doi:10.1016/j.msea.2003.10.107

${ }^{2}$ C. Suryanarayana, A. Inoue, Bulk Metallic Glasses, CRC Press, Boca Raton, London, New York 2011, 313-322

${ }^{3}$ H. Kim, K. Sumiyama, K. Suzuki, Formation and thermal stability of nanocrystalline $\mathrm{Cu}-\mathrm{Ti}-\mathrm{Ni}$ prepared by mechanical alloying, Journal of Alloys and Compounds, 239 (1996), 88-93, doi:10.1016/09258388(96)02274-8

${ }^{4} \mathrm{C}$. $\mathrm{Hu}, \mathrm{H}$. Wu, Formation of $\mathrm{Cu}-\mathrm{Zr}-\mathrm{Ti}$ amorphous powders with Band $\mathrm{Si}$ additions by mechanical alloying technique, Journal of Alloys and Compounds, 434-435 (2007), 390-393, doi:10.1016/ j.jallcom.2006.08.219

${ }^{5}$ A. Inoue, B. Shen, A. Takeuchi, Fabrication, properties and applications of bulk glassy alloys in late transition metal-based systems, Materials Science and Engineering A, 441 (2006), 18-25, doi:10.1016/j.msea.2006.02.416

${ }^{6}$ C. K. Kim, H. S. Lee, S. Y. Shin, J. C. Lee, D. H. Kim, S. Lee, Microstructure and mechanical properties of $\mathrm{Cu}$ - based bulk amorphous alloy billets fabricated by spark plasma sintering, Materials Science and Engineering A, 406 (2005), 293-299, doi:10.1016/ j.msea.2005.06.043

Z. H. Chu, H. Kato, G. Q. Xie, G. Y. Yuan, W. J. Ding, A. Inoue, Consolidation and mechanical properties of $\mathrm{Cu}_{46} \mathrm{Zr}_{42} \mathrm{Al}_{7} \mathrm{Y}_{5}$ metallic glass by spark plasma sintering, Journal of Non-Crystalline Solids, 358 (2012), 1263-1267, doi:10.1016/j.jnoncrysol.2012.02.027
${ }^{8}$ C. Suryanarayana, Recent developments in mechanical alloying, Reviews on Advanced Materials Science, 18 (2008), 203-211

${ }^{9}$ M. Adamiak, Mechanical alloying for fabrication of aluminium matrix composite powders with Ti-Al intermetallics reinforcement, Journal of Achievements in Materials and Manufacturing Engineering, 31 (2008), 191-196

${ }^{10}$ The Engineering ToolBox /cited 2014-07-10/. Available from World Wide Web: http://www.engineeringtoolbox.com/melting-temperature-metals-d_860.html

${ }^{11}$ R. Nowosielski, R. Babilas, G. Dercz, L. Pajak, J. Wrona, Structure and properties of barium ferrite powders prepared by milling and annealing, Journal of Achievements in Materials and Manufacturing Engineering, 22 (2007), 45-48

${ }^{12}$ R. Nowosielski, R. Babilas, G. Dercz, L. Pająk, Microstructure of composite material with powders of barium ferrite, Journal of Achievements in Materials and Manufacturing Engineering, 17 (2006), 117-120

${ }^{13}$ K. Shengzhong, F. Liu, D. Yutian, X. Guangji, Synthesis and magnetic properties of $\mathrm{Cu}$-based amorphous alloys made by mechanical alloying, Intermetallics, 12 (2004), 1115-1118, doi:10.1016/j.intermet.2004.04.007

${ }^{14}$ A. Guwer, R. Nowosielski, A. Borowski, R. Babilas, Fabrication of copper-titanium powders prepared by mechanical alloying, Indian Journal of Engineering \& Materials Sciences, 21 (2014), 265-271 